\title{
Terracing Recovers the Quality of a Riverbank Soil Degraded by Water Erosion in Brazilian Semiarid
}

\author{
Alisson Jadavi Pereira da Silva ${ }^{1}$ (D), Márcio Lima Rios ${ }^{2}$ \\ ${ }^{1}$ Instituto Federal de Educação, Ciência e Tecnologia Baiano - IF Baiano, Governador Mangabeira/BA, Brasil \\ ${ }^{2}$ Instituto Federal de Educação, Ciência e Tecnologia Baiano - IF Baiano, Senhor do Bonfim/BA, Brasil
}

\begin{abstract}
Soil physical-hydraulic properties are among the most important indicators for evaluating soil quality. This study aimed to experimentally demonstrate how the construction of terraces can affect physical-hydraulic properties of a soil degraded by water erosion on the banks of the Salitre river, tributary of the São Francisco river. An area in advanced stage of degradation by water erosion was delimited for the construction of a level bench terrace. The experiment was conducted for two years. Soil physical-hydraulic properties were determined before and after terracing. Time-domain reflectometry (TDR) was used to measure soil water storage (mm). This study demonstrated that terracing positively affected soil physical-hydraulic properties in the previously degraded area, allowed the increase in the retention and availability of water in the soil, thus is an ecologically beneficial practice for recovery of degraded soils on the banks of the Salitre river.
\end{abstract}

Keywords: gully; soil degradation; semi-arid. 


\section{INTRODUCTION}

Soil is a non-renewable resource and its loss may cause serious socioeconomic consequences, such as sedimentation of rivers, loss of soil productivity and desertification (Ochoa et al., 2016; Palacio et al., 2014). According to Brady \& Weil (2016), most soil degradation $(\sim 85 \%)$ results from the action of erosion caused by wind and water. In ecosystems that lose vegetation cover, the destructive power of wind and water is accelerated, triggering a rapid process of soil and water degradation, responsible for reducing biodiversity.

Many areas in the Brazilian semi-arid region begin to undergo an accelerated loss of soil and water caused by a long period of exploitation of mineral and plant resources, as well as the use of soil - without conservation practices - for agricultural activity and pasture formation. Many areas of the semi-arid region previously covered by a peculiar vegetation, adapted to long drought periods and high temperatures, have been gradually replaced by agricultural crops and pastures, which became susceptible to erosion due to the lack of soil conservation measures.

In this context, in the middle course of the Salitre river, tributary of the São Francisco river, the soil and water are in advanced degree of degradation by water erosion. After centuries of intense extractivism and extensive farming, a very noticeable aspect in the middle course of the Salitre river nowadays is the gully erosion formed by the intense process of linear erosion, which moves large portions of sediments from the slopes to the Salitre river channel (Figure 1). According Poesen et al. (2003) gully erosion is defined as the erosion process whereby runoff water accumulates and often recurs in narrow channels and, over short periods, removes the soil from this narrow area to considerable depths. The main causes of gully formation are anthropogenic factors, as the clearing of native forests and tilling of fallow lands (Sidorchuk, 1999).

Unfortunately, the Salitre river is silted due to water erosion, caused by the removal of native vegetation, establishment of pastures and crops, without the adoption of any soil conservation practice. The consequences of erosion at the site are mainly the reduction in biodiversity, siltation, which led to the interruption of the river flow even in the rainy periods, and the transport of a large load of sediments to the bed of the main river of the basin. This is worrying because it is a triggering effect in the most important water basin of the Brazilian semi-arid region: the São Francisco river basin.

Indeed, according to Figure 2, in the middle course of the Salitre river there are marks of environmental degradation associated with abandoned houses, configurating a probable beginning of a desertification process.

Unfortunately, the practice of desilting in Brazil has been used to recover the water flow of rivers, including the Salitre river: see CODEVASF (2017).
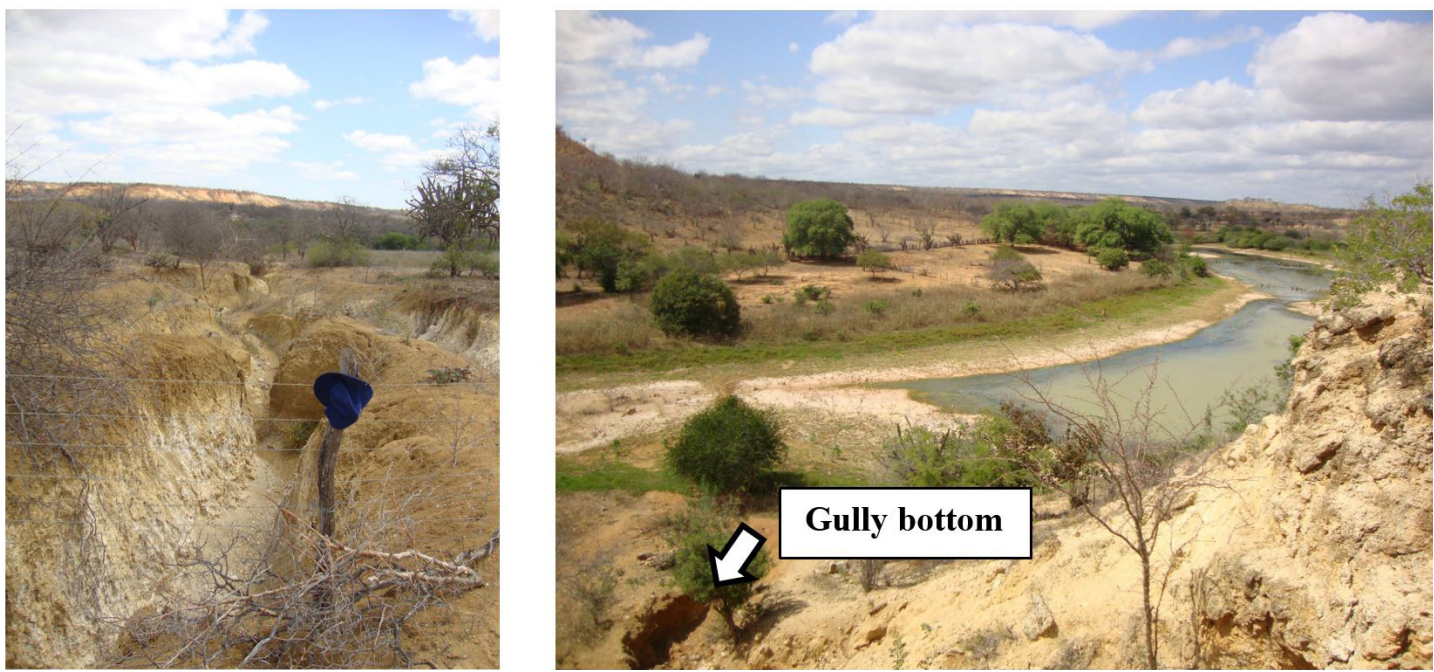

Figure 1. Typical gullies on the Salitre riverbanks (left); and sedimentation in the Salitre river (right). 

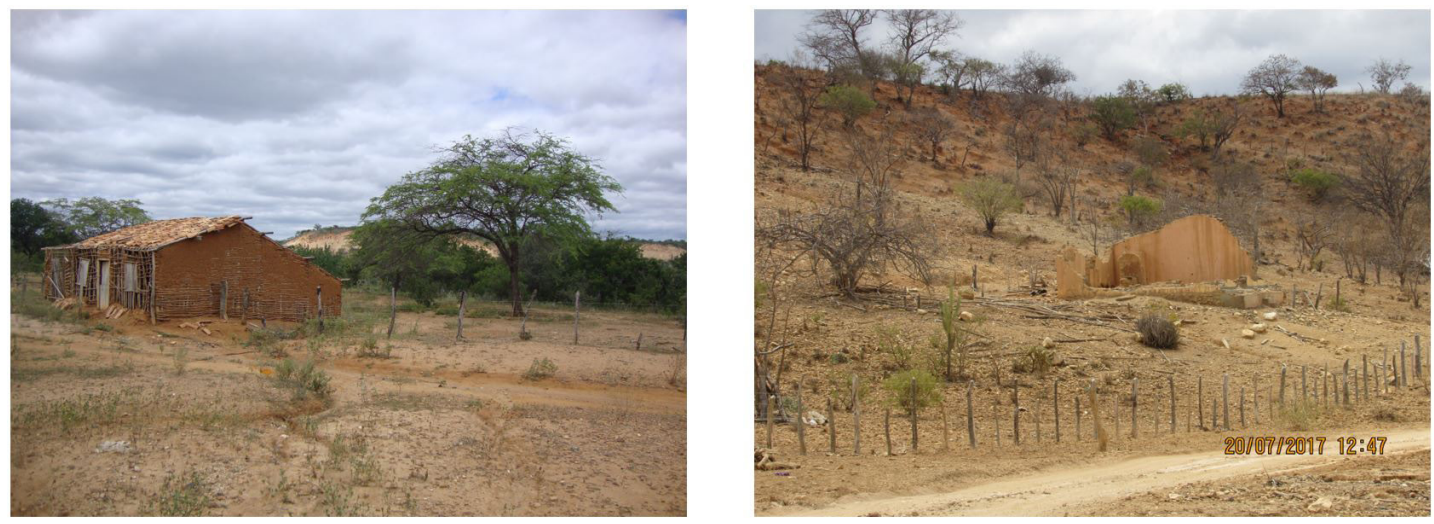

Figure 2. Marks of soil erosion and early signs of desertification in the Salitre river basin.

However, desilting is a practice that acts on the effect and not on the cause of the process. Obviously, it does not solve the problem. In the case of the Salitre river, the problem of siltation is found on the banks of the river: there is no vegetation and/or there is no interruption in the flood flow.

The effectiveness of strategies used to prevent, recover or attenuate water erosion may vary according to factors of soil, climate and vegetation cover. Many specialists agree that the predominant factors controlling soil erosion severity are precipitation, topography and vegetation cover (Yuksel et al., 2008). Nonetheless, it has long been recognized that, even when these factors remain constant, soil loss will also depend on the variations in soil properties (Bryan, 1968). Hardly one single method will effectively control water erosion and facilitate the recovery of degraded areas with different characteristics.

Terraces are barriers capable of intercepting and storing the water flow from rainfall. Building of terraces and subsequent revegetation may change soil physical-hydraulic properties, such as water retention and availability in the soil, favor the protection of the production potential of the land - or even restore its quality, leading to joint improvement in physical, chemical and biological properties - allowing the cultivation of vegetables for both human and animal consumption.

Experimental demonstrations revealing how to recover the quality of degraded soils are particularly useful to create and improve environmental programs and projects for water basins, considering their specificities in terms of soil, climate and vegetation.
Thus, the recovery of degraded areas has become a priority to combat the environmental degradation processes to which natural areas are exposed (Martins, 2007; Fagundes et al., 2018). Given the above, the present study aimed to demonstrate experimentally the possibility of recovering the quality of a soil and provide the basis for recovering an area affected by water erosion on the banks of the Salitre river, tributary of the São Francisco river.

\section{MATERIAL AND METHODS}

\subsection{Field experimental setup}

The study was conducted from May 2015 to May 2017. The experimental area is located in the middle course of the Salitre river, municipality of Campo Formoso-BA, northern Bahia, Brazil. The Salitre river basin is part of the São Francisco river basin and presents an area of $14,136 \mathrm{~km}^{2}$ with a semi-arid environment. The Salitre river is $333,024.00 \mathrm{~m}$ long, rising in the municipality of Morro do Chapéu-BA and flowing into the São Francisco river in the territory of the municipality of Juazeiro-BA. Mean annual rainfall in the basin is $500 \mathrm{~mm}$, and the average annual water deficit is $709 \mathrm{~mm}$.

In May 2015 an experimental area of $1,200 \mathrm{~m}^{2}$ in advanced degree of degradation by water erosion with slope of $17 \%$, was delimited on the bank of the Salitre river. The delimited area had two gullies erosions, which were filled by moving soil from the degraded area. Posteriorly, a bench terrace was constructed. In order to do so, we used the 18-hour service of a backhoe. Figure 3 (top) presents the geographic location 

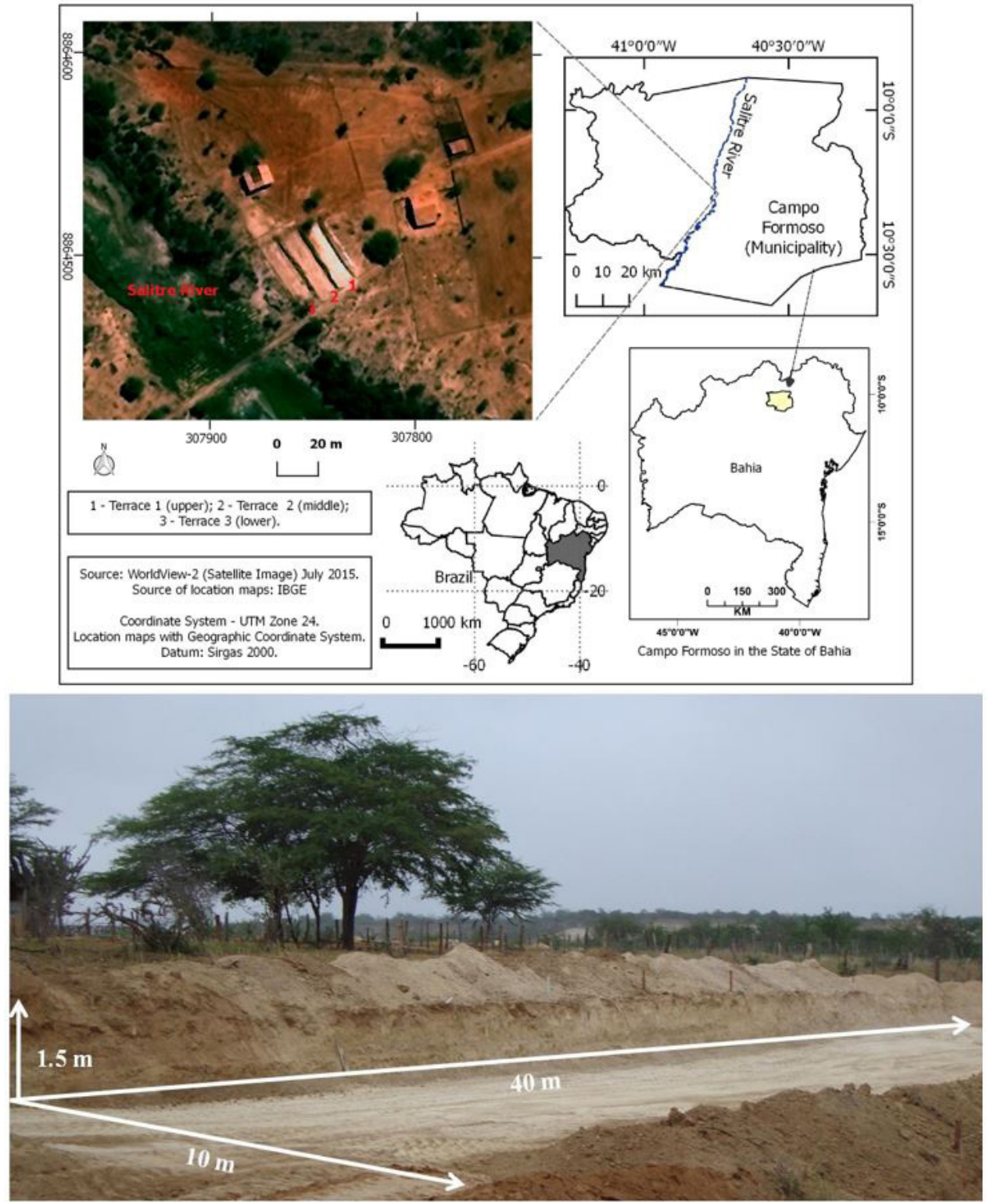

Figure 3. Geographic location of the experimental area (top); and view of the upper bench built (bottom).

of the experimental area, showing the terrace built. The terrace was composed of three $10 \times 40 \mathrm{~m}$ benches (Figure 3 - bottom).

In October 2015, three grass species and two leguminous species were sown in mixed form on the terrace: Cymbopogon citratus, D.C., Stapf.; Tifton 85 grass (Cynodon spp.); Elephant grass (Pennisetum purpureum Schum.); Cajanus cajan (L.) Mill sp. and Canavalia ensiformis (L.), DC. Aiming to guarantee the germination and growth of the planted species, a micro-sprinkler irrigation system was installed on the terrace. Two irrigation lines were set up per bench, each line containing 10 emitters ( 32 L. $h^{-1} /$ each). Each emitter wetted about $7 \mathrm{~m}^{2}$. The total wet area on each bench was approximately $140 \mathrm{~m}^{2}$, corresponding to $75 \%$ of the total terraced area. Irrigation was carried out every three days. In the first month, each irrigation depth on the terrace was $2.5 \mathrm{~mm}$ (corresponding to 1 hour of system operation). In the other months, the applied depths were $5 \mathrm{~mm}$ (corresponding to 2 hours of system operation). The water used for irrigation came from an artesian well located about $800 \mathrm{~m}$ from the area. 
Precipitation data collected at 30-minute intervals were obtained by the Salitre Agrometeorological Station, managed by EMBRAPA Semiárido.

In order to record the recovery of the degraded area, a photographic monitoring was carried out to determine changes in the area. According to Hall (2001), photographic monitoring is a fast, simple and effective way to determine if the changes made to an area have been successful. Photographic monitoring has been used in several studies to evidence changes (Munro et al., 2008; Nyssen et al., 2009; Gebremeskel et al., 2018).

\subsection{Water-retention characteristics and related physical properties of soil}

Disturbed and undisturbed soil samples were collected in two periods: initially, when the area had the gullies (2015), and two years after the terraces were built (2017)

The undisturbed soil samples were collected at $0.15 \mathrm{~m}$ depth (in three replicates) using stainless-steel rings $\left(100 \mathrm{~cm}^{3}\right)$, taken to the laboratory, and subjected to $1,3.3,10,30$ and $150 \mathrm{~m} \mathrm{H}_{2} \mathrm{O}$ pressures using a pressure-plate apparatus. Hydraulic properties were expressed using the Van Genuchten (1980) equation system:

$$
\begin{cases}\theta(\mathrm{h})=\theta_{\mathrm{s}} & \mathrm{h} \geq 0 \\ \theta(\mathrm{h})=\theta_{\mathrm{r}}+\left(\theta_{\mathrm{s}}-\theta_{\mathrm{r}}\right)\left[\frac{1}{1+|\alpha \mathrm{h}|^{\mathrm{n}}}\right]^{\left(1-\frac{1}{\mathrm{n}}\right)} & \mathrm{h}<0\end{cases}
$$

in which $\Theta$, , r and $\Theta$ s are water content, residual water content and saturated water content $\left(\mathrm{m}^{3} \mathrm{~m}^{-3}\right)$, respectively, $\mathrm{h}$ is pressure head $(\mathrm{m}), \alpha\left(\mathrm{m}^{-1}\right)$ and $\mathrm{n}$ are empirical parameters. Parameters for equation 1 were obtained using RETC, version 6.02 (van Genuchten et al., 2009).

The disturbed soil samples were used to calibrate the TDR probes (three $0.1 \mathrm{~m}$ rods, spaced 0,017 $\mathrm{m}$ ) - as proposed by Topp et al. (1980) - to obtain a $3^{\text {rd }}$ - degree polynomial relation between soil water content (SWC) and dielectric constant (DC). SWC was obtained using a precision balance, $5 \mathrm{~kg} \mathrm{x} 1 \mathrm{~g}$, and DC using a time-domain-reflectometry (TDR) device (Campbell TDR100). These disturbed samples were air-dried and sieved. Then, the soil was placed into the tubes (0.1-m-diameter and 0.2-m-high) to obtain the same density found in the field. At the bottom of each tube, a fine screen was installed to allow only water to flow out of the tube. The soil inside the tubes was saturated for 24 hours and one TDR probe was inserted in each tube. After being saturated, the soil was dried. During the soil drying, several values of SWC and DC were obtained to establish the 'SWC x DC' relationship.

In the field, SWC values were measured based on DC values obtained with TDR at three different times after a natural rainfall: 8, 264 and 456h. SWC data were obtained at two soil depths ( 0.1 and $0.3 \mathrm{~m})$ on each bench and in the degraded area located beside the terrace. In each site, SWC was measured in three replicates. After obtaining SWC data, (SWS) was determined for the degraded and recovered areas using equation 2 :

$\mathrm{SWS}=\int_{0}^{\mathrm{L}} \theta(\mathrm{z}) \mathrm{dz}$

where: $\mathrm{L}$ is the total depth considered $(0-0.4 \mathrm{~m})$; $\mathrm{z}$ is the soil layer; and $\Theta$ is soil water content.

At each one of the different times (8,264 and 456h), SWS means obtained in the degraded area (located beside the terrace) and at the upper, middle and lower terraces were compared by Tukey test at 0.05 probability level.

\section{RESULTS AND DISCUSSION}

\subsection{Recovery of the degraded area}

Some photos from the photographic monitoring carried out between 2015 and 2017 are shown in Figure 4. Indeed, these results are a demonstration of the actual possibility of vegetation recovery, thus minimizing the risk of soil erosion on the banks of the Salitre river, tributary of the São Francisco river. Perhaps, the same tractor-hour time commonly used in government programs for the desilting of rivers, including the Salitre river, as can be verified in CODEVASF (2017), can be used in practices that allow riverbanks to be revegetated.

Along the two years of research the total rainfall at the site was $667 \mathrm{~mm}$. There were two rainy periods: a shorter one, from January to February 2016 (399 mm) and a longer one, from October 2016 to April 2017 $(268 \mathrm{~mm})$. The first rainfall occurred 8 months after the terraces were built, totaling $377 \mathrm{~mm}$ in January 2016. During the experimental period, the maximum intensity recorded was $18 \mathrm{~mm} / 30 \mathrm{~min}$. 

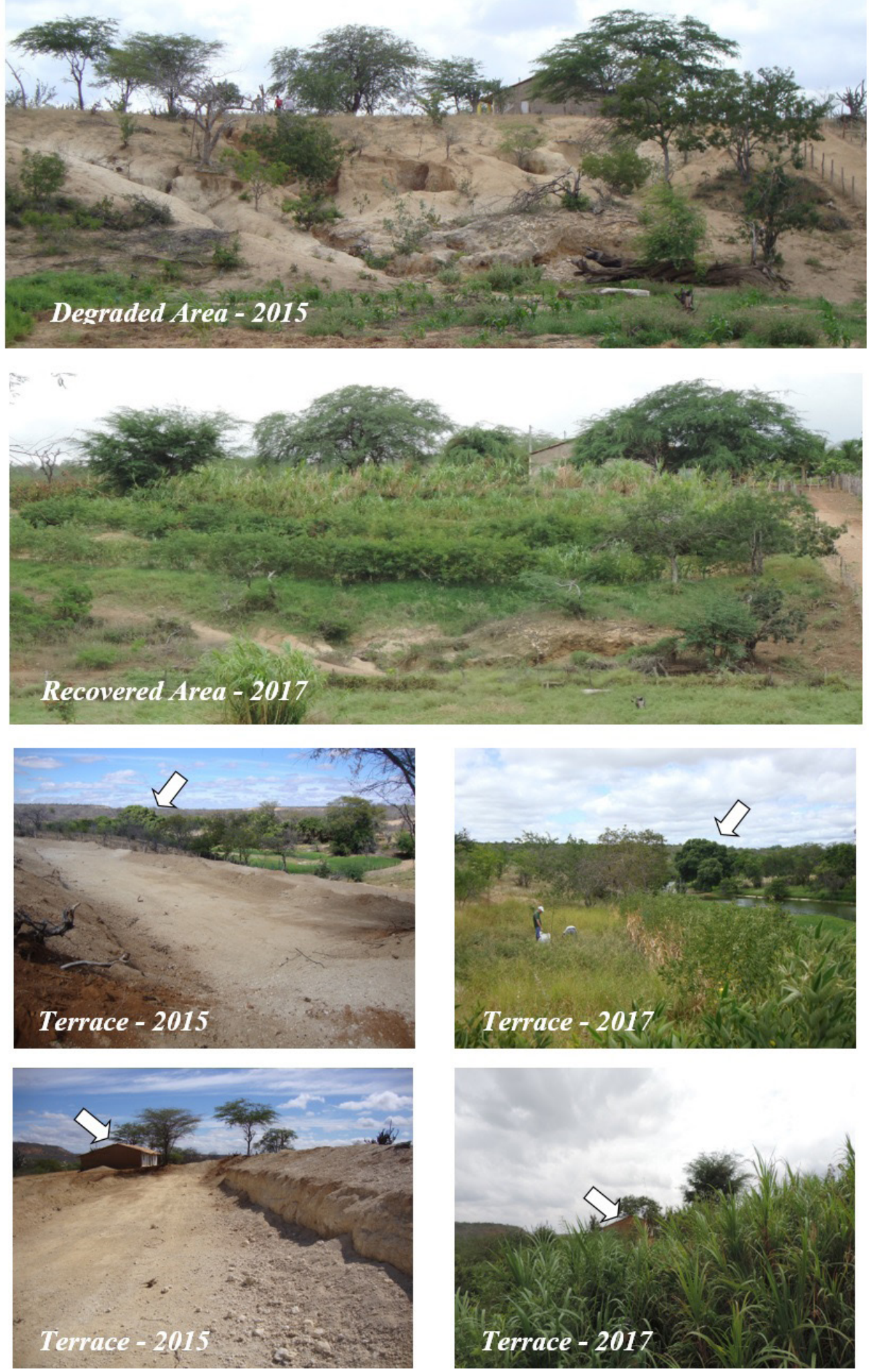

Figure 4. Photographic evidence of recovery of a degraded area on the banks of the Salitre river, tributary of the São Francisco river. 
After both rainy periods, the terraces remained preserved and new gullies did not form in the terraced area. The terraces acted as effective barriers against erosion, attenuating the erosive forces of the runoff formed uphill. Barriers against erosion are widely used to recover degraded areas because they reduce the erosive energy of the runoff and increase rainwater infiltration into the soil (Fernández \& Vega, 2016; Kimiti et al., 2017; Gispert et al., 2017), thus presenting themselves as an effective option to avoid water erosion in the middle course of the Salitre river. Despite all these positive effects, the terraces alone may not be effective in the studied region due to the long drought periods. Long drought periods, also common in the São Francisco basin, require the integration of irrigation in the projects and programs of riparian revegetation.

All grass and leguminous species grown on the terrace developed well (dry matter data were not obtained). Planting grass species in degraded areas has the advantage of covering soil surface in a short time, rapidly responding to the short period of increase in soil water availability. Alternating grass species with leguminous species combines the rapid covering effect with the restoration of soil fertility. In addition to the development of grass and leguminous species, various spontaneous species appeared in the area, such as: 'flor-do-guarujá' (Turnera ulmifolia L.); 'capim pé-de-galinha' (Eleusine indica L.); 'malva-branca'
(Sida cordifolia L.); 'cardo santo' (Cnicus benedictus L.); 'catingueira' (Poincianella bracteosa Tul.); 'malícia' (Mimosa pudica L.). Gaoa et al. (1998) observed that one of the results of returning the root system to the soil was the reduction in density and increase in porosity. Vegetation cover is one of the most effective methods of soil surface protection and minimization of erosion and particle detachment (Wang et al., 2016; Liu et al., 2014a; Liu et al., 2014b). A study conducted by Wang et al. (2016) on the Loess Plateau in China, in a $640,00 \mathrm{~km}^{2}$ area inhabited by 50 million people revealed that building terraces reduced by $0.21 \mathrm{Gt}$ year $^{-1}$ the transport of sediments between the years 1951 and 1999.

\subsection{Water-retention characteristics and related physical properties of soil}

Prior to terracing the degraded area had higher concentration of coarser particles ( $42 \pm 16 \%$ of sand and $32 \pm 9 \%$ of clay), resulting from the sheet erosion process, which initially displaces most of the finer particles. After construction of the terraces, silt and clay contents in the $0-0.2 \mathrm{~m}$ layer increased by 6 and $8 \%$, respectively, due to the exposure of previously deeper horizons caused by the formation of benches.

Figure 5 presents the DC $x$ SWC relationships obtained for the soils of the area under degradation and two years after the terraces were built:

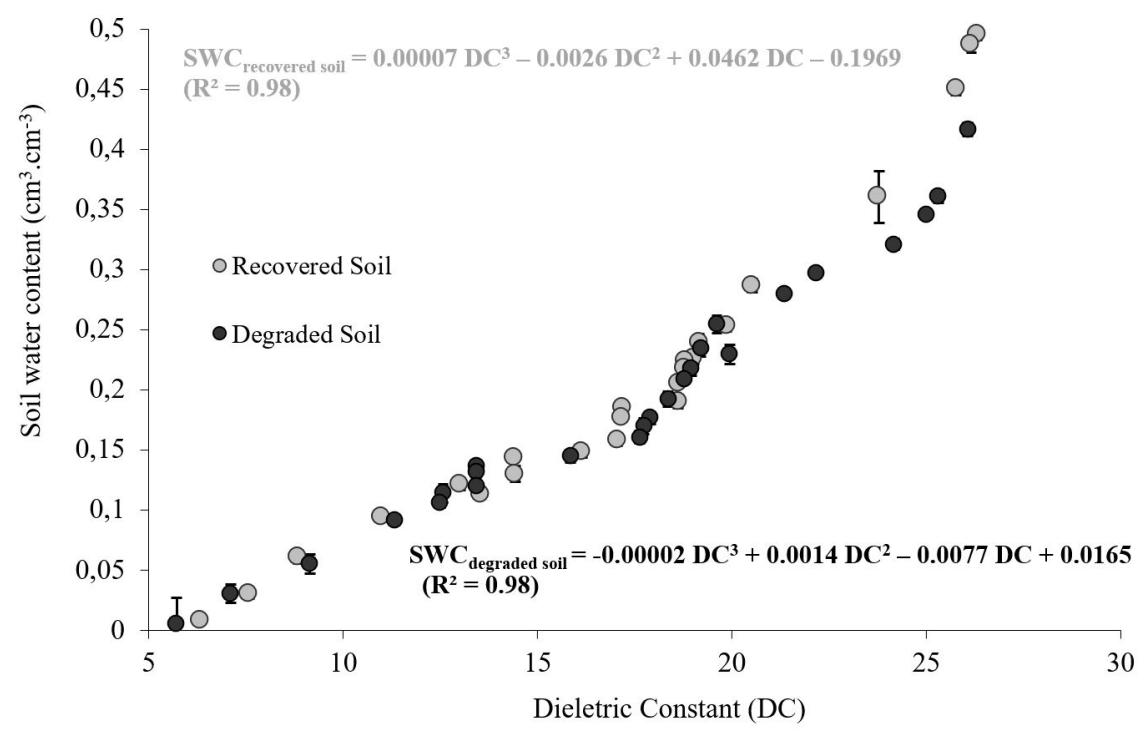

Figure 5. Relationships between Dielectric Constant (DC) and soil water content (SWC) for recovered and degraded soils. 
For DC $>25$ the gravimetric soil water content was higher in the terraced area than in the degraded area. According to Ledieu et al. (1986), the dielectric constant of a soil (DC) depends on the proportion between the components air $(\mathrm{DC} \sim 1)$, water $(\mathrm{DC} \sim 81)$ and soil particles $(\mathrm{DC} \sim 4)$. Any alteration in the features texture, structure, density and porosity of a soil affects the "DC" value attributed to the soil particles. If, for the same DC, a soil began to show higher SWC, an increase in soil water retention capacity is assumed, which favors revegetation in a degraded area.

The Soil Water Pressure head (SWP) x SWC relationship corroborates the obtained DC x SWC relationship. After terracing and revegetation, water retention characteristics were altered in the previously degraded soil, which began to retain more water over the entire range of pressure, from 0 to $-15 \mathrm{~m} \mathrm{H}_{2} \mathrm{O}$. Consequently, there were alterations in soil hydraulic properties (Table 1). Considering the total available water (AW) as the difference between the SWC values related to SWP of -1 and $-15 \mathrm{~m} \mathrm{H}_{2} \mathrm{O}$, it can be observed that $\mathrm{AW}$ was changed after the terracing. Increment in SWC for the same SWP indicates improvement in soil physical-hydraulic characteristics, besides favoring plant growth and vegetation recovery (Li \& Shao, 2006). On the other hand, low water availability in the soil is the main constraint in the control of desertification (Li et al., 2004). It is verified, therefore, that the intervention in the area through the construction of terraces allowed the increase in the retention and availability of water in the soil. Thus, the data of Table 1 are particularly useful for projects of environmental intervention in the basin, as well as research on hydrological modeling, because soil hydraulic properties are the key to the use of the models.

Between October 22 and 24, 2016, a significant 73-mm rainfall fell in the experimental area. Significant difference $(\mathrm{p}<0.05)$ was found in the SWS (see eq.3) in the soils of the degraded area (located beside the terraces) and terraced area. SWS was higher in the terraced area at the three evaluation times: $8 \mathrm{~h}, 264 \mathrm{~h}$ and $456 \mathrm{~h}$ after the rainfall. In the soil of the degraded area the mean water volume stored after the rainfall was lower than the total precipitated, whereas in the soil of the terraced area the stored volume was greater than the total precipitated (Table 2). These results reveal loss of rainwater through surface runoff and/or deep drainage in the degraded area and indicate that the terraces also received surface and/or subsurface runoff from upslope areas. Thus, since water is the most limiting essential resource in arid and semi-arid ecosystems (Arneth et al., 1998; Baldocchi et al., 2004), building terraces is a particularly useful strategy to revegetate areas degraded by water erosion.

Variability was found in soil water storage within the terraced area due to the slope. Based on the coefficient of variation, the mean variability of water storage within each bench $8 \mathrm{~h}$ after the rainfall was $14 \%$. Between the benches, the variability in water storage was $45 \%$. It is concluded that in the soils of the bench terraces there will always be higher rainfall storage, regardless of their position (Table 2). Comparing the mean values of soil water storage obtained between the terraces and the degraded area, it is verified that the terrace located at

Table 1. Soil hydraulic properties obtained in the degraded and recovery area.

\begin{tabular}{|c|c|c|c|c|c|c|c|c|c|}
\hline & \multicolumn{5}{|c|}{ Soil Water Retention ( $\mathrm{m}$ water $\mathbf{x} \mathbf{~ m}^{3} \mathbf{m}^{-3}$ ) } & \multicolumn{4}{|c|}{ Soil Hydraulic Parameters } \\
\hline & $1 \mathrm{~m}$ & $3.3 \mathrm{~m}$ & $10 \mathrm{~m}$ & $30 \mathrm{~m}$ & $150 \mathrm{~m}$ & $\theta_{r}$ & $\Theta_{s}$ & $a\left(m^{-1}\right)$ & $\mathbf{n}$ \\
\hline Degraded area & 0.308 & 0.232 & 0.159 & 0.153 & 0.137 & 0.142 & 0.318 & 0.399 & 2.54 \\
\hline Recovered area & 0.419 & 0.329 & 0.234 & 0.221 & 0.204 & 0.208 & 0.430 & 0.377 & 2.52 \\
\hline
\end{tabular}

Table 2. Soil water storage at three times after rainfall in the degraded and recovered area.

\begin{tabular}{cccc} 
& \multicolumn{3}{c}{ Soil Water Storage, $\mathbf{0}-\mathbf{0 . 4} \mathbf{~ m}$ Depth $(\mathbf{m m})$} \\
\cline { 2 - 4 } Site & $\mathbf{8 h}$ & Time after rainfall & $\mathbf{4 5 6 h}$ \\
\cline { 2 - 4 } & $74.67 \mathrm{~b}$ & $\mathbf{2 6 4 h}$ & $15.62 \mathrm{~b}$ \\
\hline Upper Terrace & $84.76 \mathrm{ab}$ & $16.7 \mathrm{~b}$ & $19.12 \mathrm{a}$ \\
Middle Terrace & $138.47 \mathrm{a}$ & $20.1 \mathrm{~b}$ & $21.88 \mathrm{a}$ \\
\hline Lower Terrace & $64.60 \mathrm{c}$ & $23.8 \mathrm{a}$ & $12.60 \mathrm{c}$ \\
\hline Degraded Area & & $14.0 \mathrm{c}$ & \\
\hline
\end{tabular}

Values followed by the same letter in the column do not differ from each other by the Tukey test at $5 \%$ probability. 
the lowest part of the terrain stores water for longer time. These responses are important for planning of cultivation on the terraces and indicate that on higher terraces revegetation should be performed using crops more tolerant to water stress, with this requirement decreasing towards the lowest terrace.

\section{CONCLUSION}

Terracing and the established vegetation cover positively affected the physical-hydraulic properties of the soil in the previously degraded area, allowed the increase in the retention and availability of water in the soil, favoring the recovery of soil physical quality.

This study demonstrated the possibility of reversing soil degradation by water erosion on the banks of the Salitre river, tributary of the São Francisco river. The use of vegetated terraces may replace the currently used techniques, such as desilting, and be the key to programs and projects aiming to prevent siltation from continuing and the advancement of desertification in the middle course of the Salitre river.

\section{ACKNOWLEDGEMENTS}

This work was funded by the Fundação de Amparo a Pesquisa do Estado da Bahia - FAPESB, Edital SEMA/FAPESB, Grant Number: TAM 007/2014.

\section{SUBMISSION STATUS}

Received: 14 july, 2019

Accepted: 11 jan., 2020

\section{CORRESPONDENCE TO}

\author{
Alisson Jadavi Pereira da Silva \\ Instituto Federal Baiano, Campus Governador \\ Mangabeira, CEP 44350-000, Governador \\ Mangabeira, BA, Brasil \\ e-mail: alissonagr@gmail.com
}

\section{FINANCIAL SUPPORT}

Fundação de Amparo a Pesquisa do Estado da Bahia FAPESB, (Grant / Award Number: 'TAM 007/2014').

\section{REFERENCES}

Arneth A, Kelliher FM, McSeveny TM, Byers JN. Net ecosystem productivity, net primary productivity and ecosystem carbon sequestration in a Pinus radiata plantation subject to soil water deficit. Tree Physiology 1998; 18(12): 785-793. http://dx.doi.org/10.1093/treephys/18.12.785. PMid:12651399.

Baldocchi DD, Xu LK, Kiang N. How plant functional-type, weather, seasonal drought, and soil physical properties alter water and energy fluxes of an oak-grass savanna and an annual grassland. Agricultural and Forest Meteorology 2004; 123(1-2): 13-39. http://dx.doi.org/10.1016/j. agrformet.2003.11.006.

Brady NC, Weil RR. The nature and properties of soils. 15th ed. Columbus: Pearson; 2016.

Bryan RB. The development, use and efficiency of indices of soil erodibility. Geoderma 1968; 2(1): 5-26. http://dx.doi. org/10.1016/0016-7061(68)90002-5.

Companhia de Desenvolvimento dos Vales do São Francisco e do Parnaíba - CODEVASF. Ação da CODEVASF no rio Salitre garante água e promove recuperação hidroambiental no norte baiano: o desassoreamento vai beneficiar mais de 320 famílias de 30 comunidades de produtores familiars [online]. 2017 [citado em 14 Nov 2018]. Disponível em: https://www.codevasf.gov.br/noticias/2017-1/acaoda-codevasf-no-rio-salitre-garante-agua-e-promoverecuperacao-hidroambiental-no-norte-baiano

Fagundes MCA, Braga LL, Silva WA, Coutinho CA, Neves WV, Souza RA et al. Survival of Saplings in Recovery of Riparian Vegetation of Pandeiros River (MG). Floresta e Ambiente 2018; 25(2): 2-11. http://dx.doi.org/10.1590/21798087.021215 .

Fernández C, Vega JA. Are erosion barriers and straw mulching effective for controlling soil erosion after a high severity wildfire in NW Spain? Ecological Engineering 2016; 87: 132-138. http://dx.doi.org/10.1016/j.ecoleng.2015.11.047.

Gaoa L, Miaoa Z, Baib Z, Zhoua X, Zhaob J, Zhub Y. A case study of ecological restoration at the Xiaoyi Bauxite Mine, Shanxi Province, China. Ecological Engineering 1998; 11(1-4): 221-229. http://dx.doi.org/10.1016/S09258574(98)00036-6.

Gebremeskel G, Gebremicael TG, Girmany A. Economic and environmental rehabilitation through soil and water conservation, the case of Tigray in northern Ethiopia. Journal of Arid Environments 2018; 151: 113-124. http:// dx.doi.org/10.1016/j.jaridenv.2017.12.002.

Gispert M, Pardini G, Colldecarrera M, Emran M, Doni S. Water erosion and soil properties patterns along selected rainfall events in cultivated and abandoned terraced fields under renaturalisation. Catena 2017; 155: 114-126. http:// dx.doi.org/10.1016/j.catena.2017.03.010. 
Hall FC. Ground-Based Photographic Monitoring. Gen. Tech. Rep. PNW-GTR-503. Portland, OR: U.S. Department of Agriculture, Forest Service, Pacific Northwest Research Station; 2001. 340 p.

Kimiti DW, Riginos C, Belnap J. Low-cost grass restoration using erosion barriers in a degraded African rangeland. Restoration Ecology 2017; 25(3): 376-384. http://dx.doi. org/10.1111/rec.12426.

Ledieu J, Ridder P, Clerck P, Dautrebande S. A method of measuring soil moisture by time-domain reflectometry. Journal of Hydrology 1986; 88(3-4): 319-328.

Li XR, Ma FY, Xiao HL, Wang XP, Kim KC. Long-term effects of revegetation on soil water content of sand dunes in arid region of Northern China. Journal of Arid Envients 2004; 57(1): 1-16. http://dx.doi.org/10.1016/ S0140-1963(03)00089-2.

Li YY, Shao MA. Change of soil physical properties under long-term natural vegetation restoration in the Loess Plateau of China. Journal of Arid Environments 2006; 64(1): 77-96. http://dx.doi.org/10.1016/j.jaridenv.2005.04.005.

Liu XY, Yan S, Dang S, Lu Y, Li XY and Zhou X. Response of sediment yield to vegetation restoration at a large spatial scale in the Loess Plateau. Science China Technological Sciences 2014a;57(8): 1482-1489.

Liu XY. et al. Analysis on sediment yield reduced by current terrace and shrubs-herbs-arbor vegetation in the Loess Plateau. Journal Hydraulic Engineering. 2014b;45:1293-1300.

Martins SV. Recuperação de matas ciliares. Viçosa: Aprenda Fácil; 2007.

Munro RN, Deckers J, Mitiku H, Grove AT, Poesen J, Nyssen J. Soil landscapes, land cover change and erosion features of the Central Plateau region of Tigrai, Ethiopia: Photo-monitoring with an interval of 30 years. Catena 2008; 75(1): 55-64. http://dx.doi.org/10.1016/j. catena.2008.04.009.

Nyssen J, Haile M, Naudts J, Munro N, Poesen J, Moeyersons J et al. Desertification? Northern Ethiopia re-photographed after 140 years. The Science of the Total Environment
2009; 407(8): 2749-2755. http://dx.doi.org/10.1016/j. scitotenv.2008.12.016. PMid:19155052.

Ochoa PA, Fries A, Mejía D, Burneo JI, Ruíz-Sinoga JD, Cerdà A. Effects of climate, land cover and topography on soil erosion risk in a semiarid basin of the Andes. Catena 2016; 140: 31-42. http://dx.doi.org/10.1016/j. catena.2016.01.011.

Palacio RG, Bisigato AJ, Bouza PJ. Soil erosion in three grazed plant communities in Northeastern Patagonia. Land Degradation \& Development 2014; 25(6): 594-603. http://dx.doi.org/10.1002/ldr.2289.

Poesen J, Nachtergaele J, Verstraeten G, Valentin C. Gully erosion and environmental change: importance and research needs. Catena 2003; 50(2-4): 91-133. http:// dx.doi.org/10.1016/S0341-8162(02)00143-1.

Sidorchuk A. Dynamic and static models of gully erosion. Catena 1999; 37(3-4): 401-414. http://dx.doi.org/10.1016/ S0341-8162(99)00029-6.

Topp GC, Davis JL, Annan A. Electromagnetic determination of soil water content: measurement in coaxial transmission lines. Water Resources Research 1980; 16(3): 574-582. http://dx.doi.org/10.1029/WR016i003p00574.

Van Genuchten MT. A closed-form equation for predicting the hydraulic conductivity of unsaturated soils. Soil Science Society American Journal 1980; 44: 892-897.

van Genuchten MT, Simunek J, Leij FJ, Sejna M. Code for quantifying the hydraulic functions of unsaturated soils. Riverside, CA: University of California Riverside; 2009.

Wang S, Fu B, Piao S, Lu Y, Ciais P, Feng X et al. Reduced sediment transport in the Yellow River due to anthropogenic changes. Nature Geoscience 2016; 9(1): 38-41. http://dx.doi. org/10.1038/ngeo2602.

Yuksel A, Gundogan R, Akay AE. Using the Remote Sensing and GIS Technology for Erosion Risk Mapping of Kartalkaya Dam Watershed in Kahramanmaras, Turkey. Sensors (Basel) 2008; 8(8): 4851-4865. http://dx.doi. org/10.3390/s8084851. PMid:27873789. 